DOI: $10.34220 /$ issn.2222-7962/2020.4/14

УДК 632.4

МУЧНИСТАЯ РОСА НА ОБЬЕКТАХ ЛАНДШАФТНОЙ АРХИТЕКТУРЫ ГОРОДА ВОРОНЕЖА

\author{
кандидат биологических наук М. В. Кочергина \\ кандидат сельскохозяйственных наук Е. С. Фурменкова \\ ФГБОУ ВО «Воронежский государственный лесотехнический университет имени Г.Ф. Морозова», \\ г. Воронеж, Российская Федерация
}

Одной из патологий лиственных растений является мучнистая роса. В поражённом растительном организме нарушаются процессы метаболизма, растения отстают в росте, теряют зимостойкость и устойчивость к неблагоприятным факторам. Агрессивность мучнисторосяных грибов является основанием для изучения их биоэкологических особенностей в различных лесорастительных зонах. Актуальность подобных исследований в условиях города Воронежа обусловлена доминированием на объектах ландшафтной архитектуры лиственных растений, в той или иной степени восприимчивых к мучнистой росе. Исследования, проведённые в парковых насаждениях, показали, что комплекс патогенов - возбудителей мучнистой росы составляют 13 видов и 2 формы грибов. При этом 3 вида и 1 форма проявили себя как редкие. К обычным по частоте встречаемости были отнесены 7 видов и 1 форма патогенов. Массовыми видами, ежегодно развивающимися в парках, являются 3 вида мучнисторосяных грибов. Слабую устойчивость к заболеванию проявили барбарис обыкновенный, дуб черешчатый, клён ясенелистный и боярышник однопестичный. Признаки поражения не отмечались на осине, ольхе чёрной, иве вавилонской, вязах обыкновенном и мелколистном, робинии, груше, дубе красном, тополе душистом, спирее Вангутта, калине Бульденеж, барбарисе Тунберга. Мероприятиями по снижению распространения в парках мучнистой росы являются мониторинг, отбор посадочного материала, использование устойчивых видов, агротехнические уходы за посадками, поддержание в насаждениях оптимальных режимов инсоляции и аэрации.

Ключевые слова: ландшафтная архитектура, парковые насаждения, биологическая устойчивость насаждений, болезни растений, мучнистая роса, патогены, степень поражения растений

\title{
POWDERY MILDEW AT THE OBJECTS OF THE LANDSCAPE ARCHITECTURE OF VORONEZH
}

\author{
PhD (Biology) M.V. Kochergina \\ $\mathrm{PhD}$ (Agriculture) E.S. Furmenkova
}

FSBEI HE "Voronezh State University of Forestry and Technologies named after G.F. Morozov", Voronezh, Russian Federation

Powdery mildew is one of the pathologies of deciduous plants. In the affected plant organism, metabolic processes are disrupted. Plants lag behind in growth; lose winter hardiness and resistance to unfavorable factors. The aggressiveness of powdery mildew fungi is the basis for the study of their bioecological characteristics in various forest zones. The relevance of such studies in the conditions of the city of Voronezh is due to the dominance of deciduous plants on the objects of landscape architecture, which are more or less susceptible to powdery mildew. Studies carried out in parks have shown that the complex of pathogens (causative agents of powdery mildew) is 13 species and 2 forms of fungi. At the same time, 3 species and 1 form proved to be rare. 7 species and 1 form of pathogens were classified as common in terms of frequency of occurrence. Massive species that develop annually in parks are 3 species of powdery mildew fungi. Common barberry, English oak, ash-leaved maple and hawthorn showed weak resistance to the disease. Signs of affection were not noted on aspen, black alder, Babylonian willow, common and small-leaved elms, robinia, pear, red oak, fragrant poplar, Vangutta spirea, Buldenezh viburnum, Thunberg barberry. Measures to reduce the spread 
of powdery mildew in parks are monitoring, selection of planting material, the use of resistant species, agrotechnical planting care, maintaining optimal insolation and aeration regimes in plantations.

Keywords: landscape architecture, park plantings, biological resistance of plantations, plant diseases, powdery mildew, pathogens, degree of plant affection

\section{Введение}

Мучнистая роса является одной из наиболее распространённых и вредоносных патологий лиственных растений. Инфицированию подвержены лесные, плодовые, декоративные деревья и кустарники, газонные травы, цветочные культуры открытого и закрытого грунтов [1,4]. Патология затрагивает все зелёные части растений - стебли, листовые пластины и черешки, неодревесневшие побеги, при массовом развитии болезни инфекция развивается на бутонах, завязях и плодах. В поражённом растительном организме нарушаются процессы ассимиляции и метаболизма, растения ослабляются и отстают в росте, теряют устойчивость к неблагоприятным факторам, снижают зимостойкость. Даже незначительная степень поражения приводит к утрате декоративности, снижению экологической и эстетической значимости насаждений $[2,5]$.

Мучнистая роса вызывается сумчатыми грибами (Leotiomycetes, Ascomycota), относящимися к семейству мучнисторосяных (Erysiphaceae). Это облигатные паразиты, которые имеют в цикле развития две стадии - бесполую (конидиальную) и половую (сумчатую). В начале лета на поражённых органах появляется нежный светлый налёт, состоящий из мицелия и конидий. К осени налёт становится более плотным, и на нём образуются плодовые тела - тёмные шарообразные вместилища клейстотеции, внутри которых развиваются сумки с сумкоспорами. Весной сумкоспоры осуществляют первые заражения растений.

К факторам, способствующим распространению мучнистой росы, относится чрезмерная загущенность посадок. Особую опасность она представляет в период высокой влажности в сочетании с температурой, оптимальной для развития грибов. Развитию патологии также способствуют сильная обрезка кроны и избыток азота в почве, продлевающие вегетацию растений.
Способность к быстрому распространению на обширных территориях и захвату новых ареалов, а также значительная вредоносность мучнисторосяных грибов послужили основанием для изучения их биоэкологических особенностей в различных регионах нашей страны и за рубежом $[6,7,9,10]$.

Л. Н. Звонарёва, изучая мучнистую росу на 450 сортах роз отечественной и зарубежной селекции в условиях Никитского ботанического сада, пришла к выводу, что максимального развития данная патология достигает при температуре воздуха $11,5 \ldots 25,8{ }^{\circ} \mathrm{C}$ [3]. Автор утверждает, что именно мучнистая роса является наиболее вредоносной болезнью садовых роз, приводящей к утрате растениями декоративных свойств. В насаждениях Павловского парка, видовой состав которых насчитывает около 50 видов деревьев и кустарников, мучнисторосяные грибы представлены 14 видами, при этом преобладающими являются грибы рода Microsphaera [8]. М. А. Ветрова и др., на основании исследований, проведённых в Ботаническом саду МГУ, отметили наибольшее видовое разнообразие мучнисторосяных грибов на представителях семейства розоцветных [2].

Актуальность настоящих исследований определяется необходимостью сохранения насаждений на объектах ландшафтной архитектуры города Воронежа, повышения их биологической устойчивости и декоративности. В настоящее время участие лиственных деревьев и кустарников в системе озеленения города Воронежа составляет более $80 \%$. Учитывая восприимчивость большинства лиственных растений к мучнисторосяным грибам, проведение подобных исследований имеет определённую практическую значимость.

Цель исследований сводилась к изучению особенностей комплекса патогенов, вызывающих мучнистую росу деревьев и кустарников на объектах ландшафтной архитектуры города Воронежа, оценке их роли в снижении эстетических и санитарно-гигиенических свойств растений, а также к

\section{Лесотехнический журнал 4/2020}


разработке мероприятий по повышению биологической устойчивости растений в урбосреде.

Исходя из поставленной цели, задачи исследований включали изучение видового состава насаждений, определение распространённости мучнистой росы и степени поражения растений, идентификацию видов и форм грибов - возбудителей мучнистой росы, разработку системы защитных мероприятий, направленных на улучшение фитопатологического состояния поражённых растений.

\section{Материалы и методы}

Исследования проводились в течение 2017 2019 г.г. В работе использовался метод инвентаризации растений с определением видов по базе Плантариум [5]. Диагностику поражений осуществляли патографическим (макроскопическим) методом [4]. Видовую принадлежность фитопатогенов устанавливали с помощью определительных ключей и базы данных Index Fungorum [11].

В ходе исследований определяли степень поражения растений, распространённость болезни и оценивали частоту встречаемости патогена.

Распространённость болезни определяется отношением количества поражённых экземпляров к общему количеству учтённых растений и выражается в процентах:

$$
\mathrm{P}=\mathrm{a} / \mathrm{A} \times 100 \%
$$

где $\mathrm{P}$ - распространённость болезни, \%;

а - количество поражённых растений, шт.;

А - общее количество учтённых растений, шт.

Степень поражения является слабой, если признаки болезни имеет до 25\% листьев, средней поражено $25 \ldots 50$ \% листьев и сильной - при наличии признаков болезни у 50 и более \% листьев.

При оценке частоты встречаемости патогенов выделяли массовые виды (встречаются ежегодно на данной территории, имеют значительное распространение), обычные виды (постоянно присутствуют в насаждении, массового развития не наблюдается) и редкие виды (развиваются в насаждении в отдельные годы, только при благоприятных условиях) [4].

Объектами исследований являлись крупнейшие парки города Воронежа - центральный парк (ЦП) и парк «Алые паруса». Территория ЦП располагается в низине правобережья Воронежского водохранилища и представляет собой хорошо сохранившийся естественный фитоценоз с типичным породным составом, характерным для Воронежской нагорной дубравы. Насаждения представлены лиственными породами.

Парк «Алые паруса» располагается на левом берегу Воронежского водохранилища. Среди древесных пород в насаждении парка преобладает сосна обыкновенная (Pinus sylvestris L.), имеющая примесь лиственных деревьев и кустарников. Важно отметить, что на обоих объектах созданы посадки из декоративных кустарников различных видов, форм и сортов.

\section{Результаты и обсуждение}

В насаждениях ЦП было отмечено 29 видов и декоративных форм деревьев и кустарников, что говорит о достаточно высоком уровне биологического разнообразия насаждений (табл. 1).

Как видно из данных табл. 1, насаждения ЦП образованы представителями 13 семейств. Более 95\% всех растений составляют лиственные породы, в той или иной степени восприимчивые к мучнистой росе.

Видовое разнообразие насаждений парка «Алые паруса» представлено в табл. 2. Участие лиственных деревьев и кустарников здесь составляет около $65 \%$.

В насаждениях парка определены виды и формы растений, относящиеся к 14 семействам. Преобладание лиственных деревьев и кустарников делает возможным развитие в насаждении мучнистой росы.

Показатели, характеризующие особенности поражения растений мучнистой росой в насаждениях ЦП, приведены в табл. 3.

В ходе исследований в насаждениях ЦП мучнистая роса отмечалась на 8 видах деревьев и 5 видах кустарников. Наиболее высокая распространённость болезни в среднем за период наблюдений отмечена на дубе черешчатом (65 \%), клёнах ясенелистном (60\%) и остролистном (53\%), из кустарников - на барбарисе обыкновенном (64\%) и боярышнике однопестичном (52\%). 


\section{Природопользование}

Таблица 1

Видовой состав древесно-кустарниковой растительности ЦП

\begin{tabular}{|c|c|c|c|}
\hline $\begin{array}{l}\text { № } \\
\text { ㄱ/П }\end{array}$ & Название вида & $\begin{array}{c}\text { Жизненная } \\
\text { форма }\end{array}$ & Участие, \% \\
\hline 1 & 2 & 3 & 4 \\
\hline \multicolumn{4}{|c|}{ Семейство Сосновые - Pinaceae Lindl } \\
\hline 1 & Псевдотсуга Мензиса - Pseudotsuga menziesii (Mirb.) Franco & Д & 0,1 \\
\hline 2 & Ель сибирская - Picea obovata Ldb. & Д & 2,5 \\
\hline 3 & Ель колючая - Picea pungens Engelm. & Д & 1,8 \\
\hline \multicolumn{4}{|c|}{ Семейство Барбарисовые - Berberidaceae Juss } \\
\hline 4 & Барбарис обыкновенный - Berberis vulgaris L. & K & 2,5 \\
\hline \multicolumn{4}{|c|}{ Семейство Ильмовые - Ulmaceae Mirb } \\
\hline 5 & Вяз мелколистный - Ulmus parvifolia Jacq. & Д & 5,7 \\
\hline \multicolumn{4}{|c|}{ Семейство Буковые - Fagaceae Dumort } \\
\hline 6 & Дуб черешчатый - Quercus robur L. & Д & 2,0 \\
\hline 7 & Дуб красный - Quercus rubra L. & Д & 1,0 \\
\hline \multicolumn{4}{|c|}{ Семейство Берёзовые - Betulaceae S. F. Gray } \\
\hline 8 & Берёза повислая - Betula pendula Ehrh. & Д & 5,6 \\
\hline 9 & Ольха чёрная - Alnus glutinosa (L.) Gaerth & Д & 1,0 \\
\hline 10 & Лещина обыкновенная - Corylus avellana L. & $\mathrm{K}$ & 0,9 \\
\hline \multicolumn{4}{|c|}{ Семейство Ивовые - Salicaceae Mirb } \\
\hline 11 & Ива вавилонская (плакучая) - Salix babylonica L. & Д & 3,2 \\
\hline 12 & Ива ломкая - Salix fragilis $L$. & Д & 0,2 \\
\hline 13 & Тополь белый - Populus alba L. & Д & 0,8 \\
\hline 14 & Осина - Populus tremula L. & Д & 7,5 \\
\hline \multicolumn{4}{|c|}{ Семейство Мальвовые - Malvaceae Juss } \\
\hline 15 & Липа мелколистная - Tilia cordata Mill. & Д & 7,2 \\
\hline \multicolumn{4}{|c|}{ Семейство Розоцветные, или Розовые - Rosaceae Juss } \\
\hline 16 & Спирея Вангутта - Spiraea vanhouttei (Briot.) Zab. & K & 6,6 \\
\hline 17 & Груша обыкновенная - Pirus communis L. & Д & 0,4 \\
\hline 18 & Яблоня лесная - Malus sylvestris P. Mill. & Д & 0,3 \\
\hline 19 & Боярышник однопестичный - Crataegus monogyna Jacq. & K & 0,7 \\
\hline 20 & Почвопокровные розы «Fleurette»-Rosa acicularis Lindl. «Fleurette» & $\bar{K}$ & 9,9 \\
\hline 21 & Почвопокровные розы «Fiona» - Rosa acicularis Lindl. «Fiona» & $\mathrm{K}$ & 9,9 \\
\hline 22 & $\begin{array}{l}\text { Роза парковая «Crimson Meillandecor» - Rosa acicularis Lindl. «Crim- } \\
\text { son Meillandecor» }\end{array}$ & K & 4,3 \\
\hline \multicolumn{4}{|c|}{ Семейство Бобовые - Fabaceae Lindl } \\
\hline 23 & Робиния лжеакация - Robinia pseudoacacia L. & Д & 0,6 \\
\hline \multicolumn{4}{|c|}{ Семейство Сапиндовые - Sapindaceae Juss. } \\
\hline 24 & Клён остролистный - Acer platanoides L. & Д & 0,1 \\
\hline 25 & Клён полевой - Acer campestre L. & Д & 6,2 \\
\hline 26 & Клён ясенелистный - Acer negundo L. & Д & 1,6 \\
\hline \multicolumn{4}{|c|}{ Семейство Конскокаштановые - Hippocastanaceae Dc } \\
\hline 27 & Конский каштан обыкновенный - Aesculus hippocastanum L. & Д & 0,1 \\
\hline \multicolumn{4}{|c|}{ Семейство Жимолостные - Caprifoliaceae Juss. } \\
\hline 28 & Снежноягодник белый - Symphoricarpos albus (L.) Blake. & K & 10,2 \\
\hline \multicolumn{4}{|c|}{ Семейство Маслиновые - Oleaceae Hoffmgg. et Link. } \\
\hline 29 & Ясень обыкновенный - Fraxinus excelsior L. & Д & 7,1 \\
\hline
\end{tabular}

Источник: собственные наблюдения авторов 


\section{Природользование}

Таблица 2

Видовой состав древесно-кустарниковой растительности парка «Алые паруса»

\begin{tabular}{|c|c|c|c|}
\hline $\begin{array}{l}\text { № } \\
\Pi / \Pi\end{array}$ & Название вида & $\begin{array}{c}\text { Жизненная } \\
\text { форма }\end{array}$ & Участие, \% \\
\hline 1 & 2 & 3 & 4 \\
\hline \multicolumn{4}{|c|}{ Семейство Сосновые - Pinaceae Lindl } \\
\hline 1 & Ель колючая - Picea pungens Engelm & Д & 0,1 \\
\hline 2 & Сосна обыкновенная - Pinus sylvestris L. & Д & 35,0 \\
\hline \multicolumn{4}{|c|}{ Семейство Барбарисовые - Berberidaceae Juss } \\
\hline 3 & Барбарис Тунберга - Berberis Thunbergii DC & $\mathrm{K}$ & 1,0 \\
\hline 4 & Барбарис обыкновенный - Berberis vulgaris L. & $\mathrm{K}$ & 0,8 \\
\hline \multicolumn{4}{|c|}{ Семейство Ильмовые - Ulmaceae Mirb } \\
\hline 5 & Вяз мелколистный - Ulmus parvifolia Jacq. & Д & 0,7 \\
\hline 6 & Вяз обыкновенный, или глдкий - Ulmus laevis Pall. & Д & 1,8 \\
\hline \multicolumn{4}{|c|}{ Семейство Буковые - Fagaceae Dumort } \\
\hline 7 & Дуб красный - Quercus rubra L. & Д & 2,5 \\
\hline \multicolumn{4}{|c|}{ Семейство Берёзовые - Betulaceae S. F. Gray } \\
\hline 8 & Берёза повислая - Betula pendula Ehrh. & Д & 2,5 \\
\hline 9 & Ольха чёрная - Alnus glutinosa (L.) Gaerth & Д & 0,3 \\
\hline \multicolumn{4}{|c|}{ Семейство Ивовые - Salicaceae Mirb } \\
\hline 10 & Ива вавилонская (плакучая) - Salix babylonica L. & Д & 0,1 \\
\hline 11 & Тополь душистый - Populus suaveolens Fish. & Д & 0,5 \\
\hline 12 & Тополь пирамидальный - Populus pyramidalis L. & Д & 1,0 \\
\hline \multicolumn{4}{|c|}{ Семейство Мальвовые - Malvaceae Juss } \\
\hline 13 & Липа мелколистная - Tilia cordata Mill. & Д & 0,1 \\
\hline \multicolumn{4}{|c|}{ Семейство Розоцветные, или Розовые - Rosaceae Juss } \\
\hline 14 & Спирея Вангутта - Spiraea vanhouttei (Briot.) Zab. & $\mathrm{K}$ & 19,7 \\
\hline 15 & Рябина обыкновенная - Sorbus aucuparia L. & Д & 0,4 \\
\hline 16 & Роза Воронежская «LianeFoly»-Rosa canina L. «LianeFoly» & $\mathrm{K}$ & 7,7 \\
\hline 17 & Почвопокровные розы «Fiona» - Rosa acicularis Lindl. «Fiona» & K & 3,1 \\
\hline 18 & Роза морщинистая «Tegala» - Rosa rugosa Thunb. «Tegala» & $\mathrm{K}$ & 1,4 \\
\hline \multicolumn{4}{|c|}{ Семейство Бобовые - Fabaceae Lindl } \\
\hline 19 & Робиния лжеакация - Robinia pseudoacacia L. & Д & 0,2 \\
\hline \multicolumn{4}{|c|}{ Семейстыо Сапиндовые - Sapindaceae Juss } \\
\hline 20 & Клён ясенелистный - Acer negundo L. & Д & 0,4 \\
\hline \multicolumn{4}{|c|}{ Семейство Конскокаштановые - Hippocastanaceae Dc } \\
\hline 21 & Конский каштан обыкновенный - Aesculus hippocastanum L. & Д & 0,3 \\
\hline \multicolumn{4}{|c|}{ Семейство Жимолостные - Caprifoliaceae Juss } \\
\hline 22 & Снежноягодник белый - Symphoricarpos albus (L.) Blake. & K & 19,2 \\
\hline \multicolumn{4}{|c|}{ Семейство Калиновые - Viburnaceae Dum } \\
\hline 23 & Калина Бульденеж - Viburnum opulus L. «Roseum» & K & 0,7 \\
\hline \multicolumn{4}{|c|}{ Семейство Маслиновые - Oleaceae Hoffmgg. et Link } \\
\hline 24 & Ясень обыкновенный - Fraxinus excelsior L. & Д & 0,2 \\
\hline 25 & Сирень обыкновенная - Syringa vulgaris L. & $\mathrm{K}$ & 0,3 \\
\hline
\end{tabular}

Источник: собственные наблюдения авторов

Самая низкая распространённость мучнистой росы выявлена на лещине обыкновенной $12 \%$. Такие породы, как берёза повислая, ясень обыкновенный, каштан конский обыкновенный, ива ломкая, снежноягодник и почвопокровные розы, занимают промежуточное положение.

Важно отметить, что в ряде случае высокой распространённости патологии соответствует сильная степень поражения растений. Такую

Лесотехнический журнал 4/2020 связь мы можем наблюдать на дубе черешчатом, клёне ясенелистном и барбарисе обыкновенном. Подобная тенденция также отмечается на лещине, снежноягоднике, почвопокровных розах «Fiona» - одновременно выявлены низкая распространённость болезни и слабая степень поражения растений.

На большинстве видов растений в период наблюдений инфекция развивалась только на ли- 


\section{Природопользование}

стьях (черешках и пластинах), у дуба и барбариса симптомы болезни отмечались на листьях и молодых побегах, на почвопокровных розах обоих сортов, помимо листьев и побегов, мучнисторосяной налёт развивался и на бутонах. Обращают на себя внимание различия в показателях заболеваемости почвопокровных роз двух представленных сортов. Сорт «Fiona» проявил большую устойчивость к инфекции, распространение болезни и степень поражения растений составили $20 \%$, тогда как у сорта «Fleurette» данные показатели оказались выше - 28 \% и 40 \% соответственно.

Среди лиственных древесных пород и кустарников в условиях ЦПКиО полную резистентность к мучнистой росе проявили ива вавилон- ская, вяз мелколистный, робиния, осина, липа мелколистная, тополь белый, дуб красный, яблоня лесная, груша обыкновенная, ольха чёрная, спирея Вангутта, парковые розы «Crimson Meillandecor»».

Комплекс возбудителей мучнистой росы в насаждениях ЦП включает 11 видов и 2 формы грибов - представителей семейства Erysiphales. Все они являются узкоспециализированными облигатными паразитами, строго приуроченными к определённому виду питающего растения.

Показатели, характеризующие заболеваемость растений в парке «Алые паруса», представлены в табл. 4.

Мучнистая роса в насаждениях ЦП

\begin{tabular}{|c|c|c|c|}
\hline $\begin{array}{c}\text { Вид (сорт) } \\
\text { растения-хозяина }\end{array}$ & Вид (форма) патогенна & $\begin{array}{c}\text { Распространён- } \\
\text { ность } \\
\text { патологии, \% }\end{array}$ & $\begin{array}{c}\text { Степень } \\
\text { поражения } \\
\text { растения, \% }\end{array}$ \\
\hline Дуб черешчатый & $\begin{array}{l}\text { Microsphaera alphitoides Griffon } \\
\text { \& Maubl }\end{array}$ & 65 & 70 \\
\hline Берёза повислая & $\begin{array}{l}\text { Phyllactinia suffulta } \\
\text { (Rebent.) Sacc }\end{array}$ & 25 & 30 \\
\hline Ясень обыкновенный & $\begin{array}{l}\text { Phyllactinia suffulta } \\
\text { f. fraxini Jacz }\end{array}$ & 30 & 20 \\
\hline $\begin{array}{c}\text { Каштан конский обыкно- } \\
\text { венный }\end{array}$ & Uncinula flexuosa Peck & 22 & 25 \\
\hline Клён остролистный & Uncinula tulasnei Fuckel & 53 & 20 \\
\hline Клён ясенелистный & $\begin{array}{l}\text { Uncinula clandestine (Biv.) J. } \\
\text { Schröt }\end{array}$ & 60 & 60 \\
\hline Клён полевой & Uncinula aceris (DC.) Sacc & 23 & 30 \\
\hline Ива ломкая & $\begin{array}{c}\text { Uncinula clandestine } \\
\text { f. salicis (Biv.) J. Schröt. }\end{array}$ & 30 & 15 \\
\hline $\begin{array}{c}\text { Боярышник } \\
\text { однопестичный }\end{array}$ & $\begin{array}{l}\text { Podosphaera clandestine } \\
\text { (Wallr.) Lev }\end{array}$ & 52 & 20 \\
\hline $\begin{array}{c}\text { Барбарис } \\
\text { обыкновенный }\end{array}$ & Microsphaera berberidis (DC.) Lev & 64 & 75 \\
\hline Лещина обыкновенная & $\begin{array}{c}\text { Microsphaera coryli (Jacz.) } \\
\text { Golovin }\end{array}$ & 12 & 10 \\
\hline Снежноягодник белый & Microsphaera penicillata Wallr & 25 & 20 \\
\hline $\begin{array}{c}\text { Почвопокровные розы } \\
\text { «Fleurette» }\end{array}$ & Sphaerotheca pannosa (Wallr.) Lév & 28 & 40 \\
\hline $\begin{array}{c}\text { Почвопокровные розы } \\
\text { «Fiona» }\end{array}$ & Sphaerotheca pannosa (Wallr.) Lév & 20 & 20 \\
\hline
\end{tabular}

Источник: собственные наблюдения авторов 
Мучнистая роса в насаждениях парка «Алые паруса»

\begin{tabular}{|l|l|c|c|}
\hline \multicolumn{1}{|c|}{$\begin{array}{c}\text { Вид (сорт) } \\
\text { растения-хозяина }\end{array}$} & \multicolumn{1}{|c|}{ Вид (форма) патогенна } & $\begin{array}{c}\text { Распро- } \\
\text { странён- } \\
\text { ность } \\
\text { патологии, } \\
\%\end{array}$ & $\begin{array}{c}\text { Степень } \\
\text { поражения } \\
\text { растения, \% }\end{array}$ \\
\hline Барбарис обыкновенный & Microsphaera berberidis (DC.) Lev & 45 & 50 \\
\hline Сирень обыкновенная & Microsphaera syringae Jacz & 26 & 20 \\
\hline Берёза повислая & $\begin{array}{l}\text { Phyllactinia suffulta } \\
\text { (Rebent.) Sacc }\end{array}$ & 10 & 20 \\
\hline Ясень обыкновенный & $\begin{array}{l}\text { Phyllactinia suffulta } \\
\text { f. fraxini Jacz }\end{array}$ & 10 & 20 \\
\hline Роза Воронежская «Liane Foly» & Sphaerotheca pannosa (Wallr.) Lév & 12 & 15 \\
\hline Почвопокровные розы «Fiona» & Sphaerotheca pannosa (Wallr.) Lév & 11 & 20 \\
\hline Роза морщинистая «Tegala» & Sphaerotheca pannosa (Wallr.) Lév & 20 & 50 \\
\hline Клён ясенелистый & cinula clandestine (Biv.) J. Schröt & 40 & 10 \\
\hline Тополь пирамидальный & Uncinula adunca (Wallr.) Lev & 8 & \\
\hline Снежноягддник белый & icrosphaera penicillata Wallr & 8 & \\
\hline
\end{tabular}

Источник: собственные наблюдения авторов

В парке «Алые паруса» признаки заражения мучнистой росой были отмечены на 10 видах растений. Для большинства видов характерен незначительный уровень распространённости болезни - до 20 \%. Наиболее высокая распространённость инфекции наблюдается на барбарисе обыкновенном $(45 \%)$ и клёне ясенелистном (40 \%). На этих же растениях мы наблюдаем сильную степень поражения листьев - 50 \%. Для остальных растений, поражённых мучнистой росой, характерна слабая степень поражения - до $25 \%$.

Исследования показали, что разные виды одного рода растений проявляют неодинаковую степень устойчивости к мучнисторосяным грибам. Например, на тополе пирамидальном развивается гриб Uncinula adunca (Wallr.) Lev, тогда как тополь душистый, произрастая в этом же насаждении, проявил полную резистентность к возбудителям мучнистой росы. Среди трёх видов роз наименее устойчивой оказалась роза морщинистая «Tegala», роза Воронежская «Liane Foly» и почвопокровные розы «Fiona» проявили большую устойчивость к мучнисторосяным грибам (табл. 4).

Отсутствие признаков поражения мы отмечали на липе мелколистной, вязах обыкновенном и мелколистном, тополе душистом, дубе красном, робинии, иве вавилонской, ольхе чёрной, рябине обыкновенной, каштане конском. Среди кустар- ников устойчивость к мучнистой росе проявили спирея Вангутта, калина Бульденеж и барбарис Тунберга.

На данном объекте в состав комплекса грибов - возбудителей мучнистой росы входят 7 видов и 1 форма патогенов. При этом 5 видов и 1 форма мучнисторосяных грибов развиваются в насаждениях обоих парков. Проведя сравнительный анализ особенностей развития этих видов, мы видим, что показатели заболеваемости выше в насаждениях ЦП. На наш взгляд, это связано с более благоприятными условиями аэрации и инсоляции территории, созданными в парке «Алые паруса», инфекционное начало накапливается в меньших количествах. Вторым фактором, объясняющим более низкую распространённость здесь мучнисторосяных грибов, является присутствие в составе насаждения хвойных пород, повышающих биологическую устойчивость фитоценоза в целом благодаря выделению терпеновых соединений.

Таким образом, видовой состав фитопатогенов семейства Erysiphaceae, паразитирующих в насаждениях крупнейших парков города Воронежа, включает 13 видов и 2 формы грибов. Оценивая частоту встречаемости патогенов, следует отметить, что 3 вида и 1 форма проявили себя как редкие в изучаемых насаждениях. Это грибы, развивающиеся на каштане конском, иве ломкой, 


\section{Природопользование}

лещине обыкновенной и тополе пирамидальном. К обычным по частоте встречаемости были отнесены 7 видов и 1 форма патогенов. Они вызывают мучнистую росу берёзы, ясеня, клёнов остролистного и полевого, боярышника, снежноягодника и сирени. Массовыми видами, ежегодно развивающимися на данных объектах и наносящими значительный ущерб растениям, являются 3 вида, паразитирущие на дубе черешчатом, клёне ясенелистном и барбарисе обыкновенном. На основании проведённых исследований, учитывая показатели распространённости болезни, степень и последствия поражения растений, мучнистая роса была отнесена к умеренно вредоспособным заболевания. Наблюдения показали, что растения не всегда могут в полной мере восстановиться после искоренения инфекции. У поражённых экземпляров отмечаются различные виды деформации листьев (морщинистость, скручи-вание и др.), их преждевременное опадение, снижение темпов (прекращение) роста побегов, ослабление растений, значительная потеря декоративности. Поражение растений мучнистой росой снижает их устойчивость в отношении других факторов. Среди заражённых растений выявляются более высокие показатели заселения их сосущими (тли, клещи) и грызущими (бронзовка, пилильщики) вредителями. Это влечёт за собой их дальнейшее ослабление, а в ряде случаев приводит к отмиранию. Экологические, экономические и социальные последствия поражения растений мучнистой росой обуславливают необходимость проведения в насаждениях парков защитных мероприятий. На подобных объектах предпочтительны профилактические мероприятия, направленные на предупреждение распространения инфекции и повышение биологической устойчивости растений. Прежде всего, это своевременный прогноз развития патогенов, основанный на систематическом мониторинге. Вместе с тем, важное значение имеют тщательный отбор посадочного материала и карантинные мероприятия, использование устойчивых видов и форм растений, соблюдение правил создания насаждений и систематические уходы за ними. Активные меры защиты (обработка растений химическими веществами) допустима при значительном распространении болезни.
Проведённые исследования позволяют сделать следующие выводы.

1. На объектах ландшафтной архитектуры города Воронежа доминируют лиственные деревья и кустарники. Важнейшей патологией ассимиляционного аппарата лиственных растений является мучнистая роса, наносящая урон не только их декоративным качествам, но и значительно ослабляющая растительный организм, способствуя его заселению другими болезнями и вредителями.

2. Комплекс патогенов - возбудителей мучнистой росы на объектах исследований составляют 13 видов и 2 формы грибов. При этом редкими для парковых насаждений являются 3 вида и 1 форма, к обычным были отнесены 7 видов и 1 форма, к массовым - 3 вида мучнисторосяных грибов.

3. В условиях парков наименее устойчивыми к мучнистой росе видами являются барбарис обыкновенный, дуб черешчатый, клён ясенелистный и боярышник однопестичный. Благоприятную среду для развития мучнисторосяных грибов создают густые посадки лиственных пород, без примеси хвойных видов. Тем не менее, полную резистентность проявили осина, ольха чёрная, ива вавилонская, вязы обыкновенный и мелколистный, робиния, яблоня, груша, дуб красный, тополь душистый, спирея Вангутта, калина Бульденеж, барбарис Тунберга.

4. При выборе ассортимента растений для озеленения общественных пространств, где применение активных мероприятий по защите растений ограничено, следует отдавать предпочтение устойчивым видам, а также стремиться к созданию смешанных по составу насаждений, формируя в них полуоткрытый тип пространственной структуры в целях оптимизации режимов аэрации и инсоляции.

Лесотехнический журнал 4/2020 


\section{Природользование}

\section{Библиографический список}

1. Благовещенская, Е. Ю. Фитопатогенные микромицеты Звенигородской биологической станции имени С. Н. Скадовского / Е. Ю. Благовещенская // Вестник Московского университета. Серия 16. Биология. - 2014. - № 2. - С. 42-45.

2. Ветрова, М. А. Ржавчинные (Pucciniales, Basidiomycota) и мучнисторосяные (Erysiphales, Ascomycota) грибы древесных растений Ботанического сада МГУ на Воробьёвых горах / М. А. Ветрова, Л. В. Гарибова, М. Ю. Дьяков, О. В. Штаер // Бюллетень Московского общества испытателей природы. Отдел биологический. - 2017. - Т. 122. - Вып. 6. - С. 51-58.

3. Видовой состав и распространение дендрофильных грибов в разных категориях зелёных насаждений Москвы / Э. С. Соколова, Т. Б. Колганихина, Т. В. Галасьева, Л. П. Стрепенюк, М. А. Семёнова // Лесной вестник. - 2006. - № 2. - С. 98-116.

4. Звонарёва, Л. Н. Мучнистая роса садовых роз и меры борьбы с ней в Никитском ботаническом саду / Л. Н. Звонарёва // Сборник научных трудов ГНБС. - 2017. -Т. 145. - С. 258-262.

5. Кочергина, М.В.Защита насаждений на объектах ландшафтной архитектуры от вредителей и болезней : учеб. пособие / М. В. Кочергина. - Воронеж, 2015. - 268 с.

6. Плантариум. Определитель растений on-line // Открытый атлас сосудистых растений России и сопредельных стран (URL: http://www.plantarium.ru).

7. Рахимова, Е. В. Ключ для определения мучнисторосяных грибов Казахстана по семействам и родам питающих растений / Е. В. Рахимова, Г. А. Нам, Б. Д. Ермекова // Turczaninowia. - 2013. - № 16 (1). - С. $176-179$.

8. Тобиас, А. В. Материалы к изучению микромицетов заказника «Лебяжий» (Ломоносовский район Ленинградской области) / А. В. Тобиас, Н. Б. Балашова, Г. А. Кмселёв // Вестник СПбГУ. Серия 3. - 2016. Вып. 4. - С. 37-47.

9. Тобиас, А. В. Микромицеты деревьев и кустарников Павловского парка / А. В. Тобиас, С. М. Фёдорова // Вестник СПбГУ. Серия 3. - 2011. - Вып. 4. - С. 46 - 60.

10. The taxonomy of powdery mildew fungi / U. Braun, R.T.A. Cook, A. J. Inman, H.-D. Shin // The powdery mildews: a comprehensive treatise / Ed. R. Bélanger, A.J. Dik et W.R. Bushnell. - St. Paul: APS Press. 2002. - P. 13-54.

11. Huhtinen, S. The invasion history of Microsphaera palczewskii (Erysiphales) in Finland / S. Huhtinen, P. Alanco, Y. Makinen // Karstenia. - 2001. - Vol. 41 - № 1. - P. 31-36.

12. Index Fungorum: the global fungal nomenclator / CABI, CBS, Landcare Research-N (URL: http://www.indexfungorum. org).

\section{References}

1. Blagoveshchenskaya, E. YU. Fitopatogennye mikromicety Zvenigorodskoj biologicheskoj stancii imeni S. N. Skadovskogo / E. YU. Blagoveshchenskaya // Vestnik Moskovskogo universiteta. Seriya 16. Biologiya? 2014. №2. - P. $42-45$.

2. Vetrova, M. A. Rzhavchinnye (Pucciniales, Basidiomycota) i muchnistorosyanye (Erysiphales, Ascomycota) griby drevesnyh rastenij Botanicheskogo sada MGU na Vorob'yovyh gorah / M. A. Vetrova, L. V. Garibova, M. YU. D'yakov, O. V. SHtaer // Byulleten' Moskovskogo obshchestva ispytatelej prirody. Otdel biologicheskij, 2017. - T. 122. - Vyp. 6. - P. 51 - 58.

3. Vidovoj sostav i rasprostranenie dendrofil'nyh gribov v raznyh kategoriyah zelyonyh nasazh-denij Moskvy /E.S. Sokolova, T.B. Kolganihina, T.V. Galas'eva, L.P. Strepenyuk, M.A. Semyonova // Lesnoj vestnik, 2006. №2.- P. 98 - 116 . 
4. Zvonaryova, L. N. Muchnistaya rosa sadovyh roz i mery bor'by s nej v Nikitskom botanicheskom sadu / L. N. Zvonaryova // Sbornik nauchnyh trudov GNBS, 2017. -T. 145. - P. $258-262$.

5. Kochergina, M.V. Zashchita nasazhdenij na ob"ektah landshaftnoj arhitektury ot vreditelej $i$ bo-leznej: ucheb. posobie / M.V. Kochergina. - Voronezh, 2015.- 268 p.

6. Plantarium. Opredelitel' rastenij on-line // Otkrytyj atlas sosudistyh rastenij Rossii i sopredel'nyh stran (URL: http://www.plantarium.ru).

7. Rahimova, E. V. Klyuch dlya opredeleniya muchnistorosyanyh gribov Kazahstana po semejstvam i rodam pitayushchih rastenij / E. V. Rahimova, G. A. Nam, B. D. Ermekova // Turczaninowia, 2013. - № 16 (1). - P. 176 179.

8. Tobias, A. V. Materialy $k$ izucheniyu mikromicetov zakaznika «Lebyazhij» (Lomonosovskij raj-on Leningradskoj oblasti) / A. V. Tobias, N. B. Balashova, G. A. Kmselyov // Vestnik SPbGU. Seriya 3, 2016. - Vyp. 4. - P. $37-47$.

9. Tobias, A. V. Mikromicety derev'ev i kustarnikov Pavlovskogo parka / A. V. Tobias, S. M. Fyodorova // Vestnik SPbGU. Seriya 3, 2011. - Vyp. 4. - S. 46 - 60.

10. Braun, U. The taxonomy of powdery mildew fungi / U. Braun, R.T.A. Cook, A.J. Inman, H.-D. Shin // The powdery mildews: a comprehensive treatise / Ed. R. Bélanger, A.J. Dik et W.R. Bushnell. - St. Paul: APS Press, 2002. - P. 13 - 54.

11. Huhtinen S. The invasion history of Microsphaera palczewskii (Erysiphales) in Finland / S. Huhtinen, P. Alanco, Y. Makinen // Karstenia, 2001. - Vol. 41 - № 1. - P. 31-36.

12. Index Fungorum: the global fungal nomenclator / CABI, CBS, Landcare Research-N (URL: http://www.indexfungorum. org).

\section{Сведения об авторах}

Кочергина Марина Владимировна - кандидат биологических наук, доцент, доцент кафедры ландшафтной архитектуры и почвоведения ФГБОУ ВО «Воронежский государственный лесотехнический университет имени Г.Ф. Морозова», г. Воронеж, Российская Федерация; e-mail: diamond-kmv@yandex.ru.

Фурменкова Евгения Сергеевна - кандидат сельскохозяйственных наук, доцент кафедры ландшафтной архитектуры и почвоведения ФГБОУ ВО «Воронежский государственный лесотехнический университет имени Г.Ф. Морозова», г. Воронеж, Российская Федерация; e-mail: furmenkova.eu@yandex.ru.

\section{Information about authors}

Kochergina Marina Vladimirovna - PhD (Biology), Associate Professor of the Department of Landscape Architecture and Soil Science, FSBEI HE "Voronezh State University of Forestry and Technologies named after G.F. Morozov", Voronezh, Russian Federation; e-mail: diamond-kmv@yandex.ru.

Furmenkova Evgenia Sergeevna - PhD (Agriculture), Associate Professor of the Department of Landscape Architecture and Soil Science, FSBEI HE "Voronezh State University of Forestry and Technologies named after G.F. Morozov", Voronezh, Russian Federation; e-mail: furmenkova.eu@yandex.ru. 